\title{
Firm Performance in Networks: The Interplay Between Firm Centrality and Corporate Group Size*
}

\author{
Massimo Riccaboni ${ }^{1,2}, \mathrm{Xu}$ Wang $^{1}$ and Zhen $\mathrm{Zhu}^{\dagger 1,3}$ \\ ${ }^{1}$ IMT School for Advanced Studies Lucca, Italy \\ ${ }^{2} \mathrm{KU}$ Leuven, Belgium \\ ${ }^{3}$ University of Greenwich, UK
}

\begin{abstract}
Corporate groups or networks, which are defined as collections of two or more legally independent firms connected through ownership ties, are prevalent in both developed and developing countries. The separate effects of firm centrality and corporate group size on firm performance have been largely discussed in the literature. However, the effect of their interaction remains underexplored. This paper attempts to fill the gap by introducing a new normalized measure of firm centrality independent of corporate group size. Our empirical analysis is based on a set of global corporate networks encompassing 17.8 million firms and the ownership ties between them extracted from the ORBIS database in 2014. We further investigate the firm performance in the corporate networks above by gathering financial information on 483,835 Italian firms from the AIDA database from 2014-2016. We find a positive relationship between firm centrality and firm performance, but the significance of the relationship decreases as corporate group size increases.
\end{abstract}

Keywords: ownership, networks, centrality, corporate group, complexity

*The paper was previously circulated under the title "Ownership Network and Firm Performance: Evidence from Italy." The authors would like to thank the participants of the seminars at the University of Trento (2016), the IMT School of Advanced Studies Lucca (2017), the conference of the Italian Trade Study Group (2017), and the University of Greenwich (2018) for their constructive comments and suggestions. The usual disclaimer applies.

${ }^{\dagger}$ Corresponding author. Email: z.zhu@gre.ac.uk. Queen Anne Building 357, University of Greenwich, Park Row, London, United Kingdom, SE10 9LS. 


\section{Introduction}

In a corporate group or network formed by two or more legally independent firms, the exchange of a variety of tangible and intangible resources routinely occurs through the ownership ties between firms. Firms' ability to access resources highly depends on their network positions. A firm occupying a central position in the network is likely to have more opportunities to access resources and to benefit from knowledge spillovers (Powell et al., 1999; Tsai, 2001; Tsai and Ghoshal, 1998; Zaheer and Bell, 2005). However, firms in central positions incur more costs to maintain their relational ties. Furthermore, a high level of connectivity is sometimes considered to derail economic performance by making firms more vulnerable to exogenous shocks (Uzzi, 1996, 1997).

In this work, we analyze the ownership networks of corporate groups, which are defined as confederations of legally independent firms linked by multiplex ties (Almeida and Wolfenzon, 2006; Belenzon and Berkovitz, 2010; Belenzon et al., 2013) and belonging to the same owner(s) (Belenzon et al., 2017; Cainelli and Iacobucci, 2011; Cainelli et al., 2006). Firms can exchange financial capital, knowledge and managerial skills with other firms in the same group through ownership links (Blomström and Sjöholm, 1999; Markusen, 1995). However, some studies argue that a corporate group with diversified affiliates may have problems due to weak disclosure requirements, ineffective governance mechanisms, and a poorly developed market for corporate control (Khanna and Palepu, 2000; La Porta et al., 1997, 1998).

In the literature, the effects of firm positions in the corporate network and of the group-level features on firm performance have been widely discussed, but the relationship between their interaction and firm performance remains underexplored. Although a more central firm in large groups can gain more access to resources, it is more likely to confront higher costs of acquiring and communicating knowledge (Caliendo and Rossi-Hansberg, 2012) and governance frictions, which can reduce the effectiveness of central control (Bethel and Liebeskind, 1998; Patacconi, 2009). The possible trade-off effect may make central firms in a large corporate group benefit less than expected.

Through an empirical analysis, our research contributes to the literature by combining firm-level centrality and corporate group size and exploring the relationship between their interplay and firm performance. Furthermore, we provide a novel centrality measure to evaluate a firm's position in the ownership network. The measure is based on the harmonic centrality (Newman, 2003; Rochat, 2009; Schilling and Phelps, 2007), which can avoid the infinite path length problem in a network 
composed of disconnected components. However, the harmonic centrality value of a certain node is highly correlated with the component size in which the firm is located. Given this drawback, our measure adopts a normalization method to reduce the effect of the component size. In this way, we make the centrality measure more comparable across components (i.e., business groups of different sizes).

Our analysis is focused on Italian firms. We select Italy in this study for a number of reasons. First, the data on ownership relationships (and hence corporate networks) from ORBIS are difficult to cross-link over years (due to the annual updates of the database and the resulting changes in the firm identifiers). In our case, as we will discuss in detail in Subsection 3.1, we have collected the data on corporate networks in 2014 and firm performance such as sales from 2014-2016. A valid empirical analysis would therefore require that the corporate networks remain reasonably stable over the 2014-2016 period. In this regard, Italy and some other European countries have experienced a severe debt crisis since the end of 2009. The real GDP growth rate of Italy $^{1}$ had been ranked in the last $5 \mathrm{EU}$ countries for 3 consecutive years since 2012. Figure 4 in the appendix shows that the Italian economy was shocked by the crisis since 2011, and the GDP growth rate only turned positive again in 2014. During the crisis, skepticism about the availability of equity capital, as a main determinant, results in a decrease in the volume of mergers and acquisitions at the global level (Kostić, 2013), and the ownership structure of most corporate groups remained stable.

Another reason to study Italian firms is that corporate groups, especially those controlled by a person or a group of family members, are common in Italy (Corbetta and Tomaselli, 1996; Cucculelli and Micucci, 2008). In 2014, according to our dataset of global corporate networks, the number of Italian-owned corporate groups is ranked in the top 10 countries worldwide.

Finally, Italy is one of the few countries for which ORBIS by Bureau van Dijk (BvD) provides more complete data, with a coverage of at least $40 \%$ of aggregate employment (McGowan et al., 2017). Therefore, we believe that Italy is a representative country to conduct our research.

We manually download the shareholder data for 17.8 million global firms in 2014 from the ORBIS database. Based on their direct inter-firm shareholding relationships, we construct the global ownership network. Then, we restrict our sample to Italian firms and identify 483,835 Italian firms from the global ownership network and collect their financial accounts data from 2014 to 2016 in AIDA (Analisi Informatizzata Delle

\footnotetext{
${ }^{1}$ Data source: world bank https://data.worldbank.org/.
} 
Aziende Italiane), which is the Italian subset of ORBIS and is more convenient for data collection than the full version of ORBIS. Then, we empirically analyze firm centrality, corporate group size and the relationship between their interaction and firm performance, which, in our main model, is measured as the 3-year average sales growth rate. The results show a positive relationship between firm centrality and performance in small corporate groups but not always in larger corporate groups. A possible explanation for the findings is that although firms in central positions in larger corporate groups can facilitate access to funds and information, they are also faced with higher coordination costs than those in small groups.

The rest of the paper is structured as follows. In Section 2, we present the theoretical framework of our research. Section 3 introduces the sample, centrality and corporate group size measure and the econometric specifications. In Section 4, we present some descriptive statistics of the data and then provide the estimation results and analysis. Finally, Section 5 concludes the work.

\section{Theoretical Framework}

The past two decades have seen a surge of interest in applying network theory to organizational studies due to a growing awareness of complexity in business (Borgatti and Halgin, 2011; Carpenter et al., 2012; Vasconcelos and Ramirez, 2011). In organizational network theory, a vast body of literature has investigated the effect of firm position and network complexity on firm performance, especially in the context of inter-firm networks (Schilling and Phelps, 2007; Zaheer and Bell, 2005). In an inter-firm network, firms are connected through a variety of relationships such as collaboration (Ahuja, 2000; Gulati and Gargiulo, 1999; Gulati et al., 2000), interlocking directorates (Uzzi, 1997; Zaheer and Bell, 2005), ownership (Almeida and Wolfenzon, 2006; Kali and Sarkar, 2011) and credit (Peterson and Rajan, 1994).

Our work is related to the literature on corporate groups' ownership network and firm performance. Corporate groups exhibit approximately a pyramidal structure in which one or more layers of firms are controlled by the same ultimate owner either directly or through a holding company (Cainelli and Iacobucci, 2011; Goto, 1982). Due to the availability of worldwide shareholding data in recent years, a growing body of research has explored the global ownership network (Glattfelder, 2010; Vitali and Battiston, 2011; Vitali et al., 2011). Existing studies discuss the inter-firm network generally from two perspectives: the individual firm level and the network level (Provan et al., 2007). Although some works have considered the factors of both levels, the relationship between their interplay and firm performance remains 
unclear. Our research attempts to fill the gap by combining both the individual-level and network-level factors in the analysis.

\subsection{Firm-level Centrality}

Many studies have discussed the benefits of network centrality for a firm. Because network links facilitate the sharing of financial capital (Belenzon and Berkovitz, 2010), superior knowledge and managerial skills (Bernstein and Mohnen, 1998; Markusen, 1995) among firms in the corporate group, a firm occupying a central position in the network has more opportunities to access diversified knowledge and resources (Powell et al., 1996; Tsai and Ghoshal, 1998) and generate more innovations than the peripheral firms (Owen-Smith and Powell, 2004; Soh, 2003). However, despite the benefits of network ties, a high level of connectivity is sometimes considered to constrain the adaptability of firms and make them vulnerable to exogenous shocks (Uzzi, 1996, 1997).

In the literature, diverse measures are used to identify a firm's network position. Gulati and Gargiulo (1999) and Powell et al. (1996) have used closeness centrality, which measures how central a firm is relative to other firms, including both direct and indirect partners. Closeness centrality also measures the firm's reachability to every other firm with the fewest number of intermediate firms. Schilling and Phelps (2007) employ the betweenness centrality measure as a control variable, but its effect on subsequent firm patenting fails to achieve statistical significance in any of the estimated models. Mani and Moody (2014) measure a firm's position using mesolevel network structure indicators: disconnected periphery, isolated cluster, small world and nested world. They find that firms residing in the nested core have more multiplex ties and larger transaction volumes than firms in the small world or the disconnected periphery. In recent work, Kwon et al. (2016) also adopts the closeness centrality to measure how closely connected a firm is to the rest of the organizations in the inter-firm network, but they have not found evidence to support that the influence of national trust on alliance governance will decrease as a firm increases its centrality in the international alliance network.

Our research contributes to the literature by providing a novel centrality measure that is based on the harmonic closeness centrality (Newman, 2003; Rochat, 2009). An advantage of the harmonic centrality is that it can avoid the infinite path length problem compared with the traditional closeness centrality. However, the harmonic centrality value of a node is highly correlated with the size of the component in which it is located. Given this drawback, our measure adopts a normalization method to 
reduce the effect of the component size. By doing so, we make the centrality measure more comparable across components of different sizes. In the case of ownership networks, we can better assess how central a firm is in a corporate group of any size.

\subsection{Group-level Measures}

Another strand of literature focuses on network-level features and attempts to understand the impact of structures and behaviors on individual organizations (Ahuja, 2000; Powell et al., 1996; Provan et al., 2007). Some recent works have developed novel measures to characterize the complexity of a corporate group's hierarchical structure. Altomonte and Rungi (2013) provide a specific entropy-like measure of organizational complexity of hierarchical chains and find a non-linear relationship between hierarchical complexity and productivity. Belenzon et al. (2013) develop a pyramidal index (PI) that measures the distribution of firms by ownership layers. They find that Anglo groups have the most vertical hierarchical structure, while the Swiss groups have the most horizontal structures. Mahmood et al. (2017) adopt the intergroup network centralization measure introduced in Freeman (1978) and demonstrate that centralization of equity ties enhances subsidiary performance, but these effects are weakened when the environment becomes turbulent.

Existing studies have emphasized the role of individual positions in the network and group-level features on firm performance, but the relationship between their interaction and firm performance remains largely unknown. Although a central firm in a large corporate group can gain more access to information, it faces possibly higher costs of acquiring and communicating knowledge (Altomonte and Rungi, 2013; Caliendo and Rossi-Hansberg, 2012) and governance frictions, which can reduce the effectiveness of central control (Bethel and Liebeskind, 1998; Patacconi, 2009). The possible trade-off effect may make a central firm in a large corporate group benefit less than expected.

\section{Method}

\subsection{Data and Sample}

We derive the ownership data from BvD's ORBIS database. ORBIS is the largest and most widely used firm-level database, which captures information on companies, especially private ones, from a wide range of sources. The ORBIS database covers 
information on 17,842,618 global firms' equity ownership structure in $2014 .^{2}$ For each firm, there is at least one observation of its direct shareholders, and we collect each of its owners' IDs ${ }^{3}$ and the ownership shares (see the details of the data form in Table 1). Firms can have multiple direct shareholders, such as firms $\mathrm{E}$ and $\mathrm{H}$ in Table 1 . In total, there were initially 25,635,140 observations, and each firm had, on average, 1.44 direct shareholders.

A strand of studies builds the inter-firm ownership network based on the majority rule (Altomonte and Rungi, 2013; Belenzon and Berkovitz, 2010; UNCTAD, 2016). In ORBIS, $81.2 \%$ of the firms are owned by majority shareholders. Their ownership links (shares $>50 \%$ ), representing $56.53 \%$ of all the links (see Table 2), are used to build the ownership network in our study. ${ }^{4}$ For example, the 5 th and 9 th rows in Table 2 are dropped in our study. For each observation, we construct a directed link from the shareholder to the firm. Based on Table 2, for example, a directed link starting from shareholder A to firm B is built for the first observation, and then another link from shareholder B to firm $\mathrm{C}$ is built for the second observation, and so on. Some firms in the same corporate group may share the same direct owner. For example, in Table 2, firms B, D, E, and J are all owned by firm A in the corporate group. All firms that belong to the same corporate group are thus connected through ownership links. As shown in Table 2, firm A is the parent firm of the corporate group and controls all the other subsidiaries, and the ownership structure of each corporate group can be depicted as a hierarchy. ${ }^{5}$ Because there is no ownership link

\footnotetext{
${ }^{2}$ We download the data on all the firms provided with ownership information by ORBIS in January 2015.

${ }^{3} \mathrm{BvD}$ identifies each company by a unique ID. The BvD ID number incorporates either the national ID number or the ID provided by their information providers (IP). According to BvD, the ID numbers may change when the national ID numbers change in the official data sources or the BvD IPs decide to switch their ID numbers. In Italy, the BvD ID may change if the company changes address.

${ }^{4}$ We also use two other methods to build the ownership network in which minority control is considered. If a firm has no majority owner, we rank all its shareholders by their shares $r 1, r 2, r 3, \cdots$. In one method, we retain the link from the top-ranking shareholder if its share is larger than the sum of the shares of the second and the third ranking shareholders, that is, $r 1>r 2+r 3$. Similarly, in the other method, we retain the link from the top-ranking shareholder if its share is larger than the sum of the shares of the second, the third and the fourth ranked shareholders, that is, $r 1>r 2+r 3+r 4$.

${ }^{5}$ Due to data restrictions, we cannot distinguish the ownership by entities, states, individuals or families. Therefore, the one located at the top of each corporate ownership structure can be either a parent company whose shareholders are not provided by ORBIS or all have minority ownership or the individual who is the ultimate beneficial owner of the corporate group. See more details in 6.4 .
} 
among firms in different corporate groups, the global network can be divided into disconnected network components. ${ }^{6}$

According to the approach we use to build the ownership network, each firm has one shareholder except the ultimate owner, which has no shareholder. Thus, the number of entities in each corporate group is equal to the number of links plus 1 , and the number of nodes in the global ownership network is equal to the number of links plus the number of components. The global ownership network consists of 25,681,483 nodes, $14,492,929$ links and 11,188,554 components. ${ }^{7}$ In total, $96.32 \%$ of the components contain fewer than 4 nodes, while only $0.05 \%$ of them contain more than 50 nodes (i.e., firms). The largest component includes 8,419 nodes.

As mentioned above, we then restrict our sample to Italian firms. In our data, Italian-owned corporate groups represent $3.46 \%$ of all the corporate groups, ranking 8th among all countries. ${ }^{8}$ We collect the non-consolidated financial balance sheet data of Italian firms from AIDA, which is the Italian subset of ORBIS. We use AIDA instead of the full version of ORBIS because the former provides more convenient queries tailored for Italy and therefore faster data retrieval processes. It contains information on all Italian companies obliged to submit their balance sheets. We extract the data on 1,164,871 active Italian firms in all sectors and regions in $2014 .^{9}$ Among all these Italian firms provided by AIDA in 2014, we identify 483,835 in the global ownership network, which is built using the data from ORBIS ${ }^{10}$. These Italian firms belong to 372,109 components. Each of them contains at least one Italian firm,

\footnotetext{
${ }^{6}$ Because the individual majority shareholders cannot be identified in the data, some groups of size 2 are actually composed of a standalone firm and its individual shareholders. We perform a new algorithm to filter out these possible links. See more details in 6.4 in the appendix.

${ }^{7}$ The network built using the other two methods is composed of $26,266,255$ nodes, $14,873,254$ links for the definition $r 1>r 2+r 3$, and 26,168,532 nodes, 14,814,218 links for the definition $r 1>r 2+r 3+r 4$.

${ }^{8}$ In our data, the 10 most frequent countries where the ultimate owners of all the corporate groups are located include United States (12.34\%), Russia (9.43\%), Norway (4.96\%), Poland (4.90\%), Australia (4.88\%), Germany (4.71\%), Bulgaria (4.25\%), Italy (3.46\%), Romania (2.50\%) and Spain $(1.51 \%)$.

${ }^{9}$ In February 2016, we downloaded the Italian firms' balance sheet data for the year 2014. In 2017, we further downloaded their balance sheet data for the years 2015-2016, but some firms were no longer found in AIDA. See the descriptive statistics in Table 3.

${ }^{10}$ We first match the Italian firms in AIDA with those in the original ORBIS ownership databases by their BvD ID and identify 711,393 firms. Considering that some of them may change the BvD ID number, we further match the rest of the firms by their names and identify 7,751 firms. In total, we find 719,144 Italian firms with ownership information in AIDA. However, 235,309 of them have no majority owners. According to our definition, we cannot identify which corporate group these firms belong to. Finally, we retain 483,835 Italian firms for further analysis.
} 


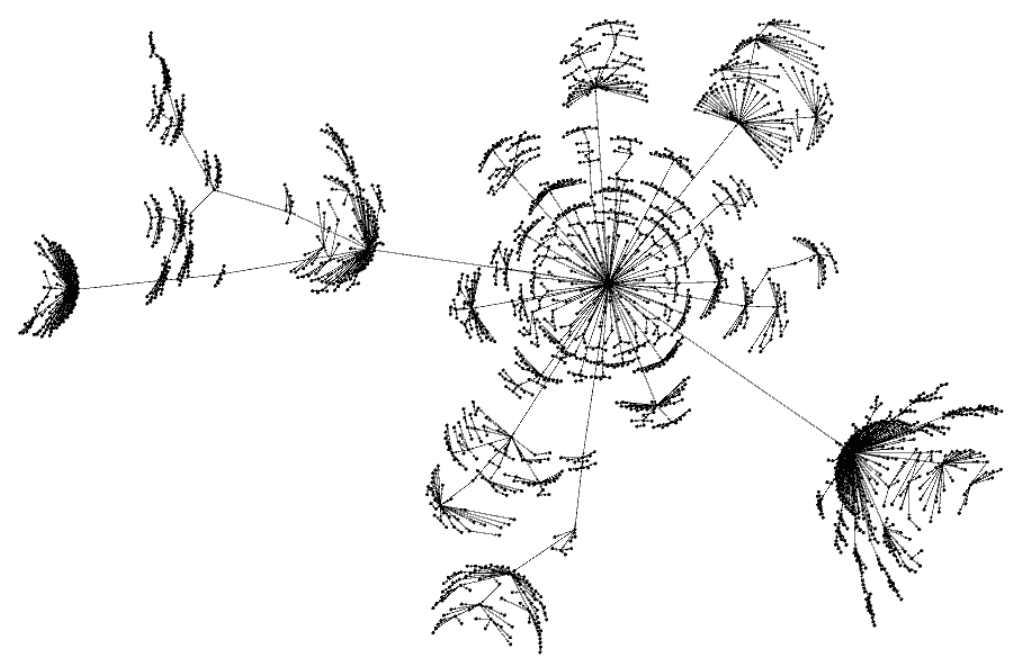

Figure 1: The Ownership Structure of a Large Corporate Group

and some of them also contain foreign firms. Only 25 of these groups are composed of more than 1,000 firms (see an example in Figure 1), and the largest one contains 3,260 firms.

Our final sample of data is subject to several limitations. First, we have only crosssectional data on the ownership structure, which is standard in the literature because it is difficult to trace its change over time. Due to this restriction, we cannot properly test the causal effect of centrality on corporate performance.

Second, we have limited information about the shareholders in the current data. As a result, a corporate group defined in our work may also include its ultimate beneficial owner who controls the parent company. Although it is necessary to distinguish different types of ownership, how to address the ultimate individual or family beneficial owners requires more attention in future work. If firms are directly controlled by the same ultimate beneficial owner(s), they can be viewed as members of a group rather than independent because their business can be related in some way. Cainelli and Iacobucci (2011) and Belenzon et al. (2017) define these firms as members of a corporate group. In the case of Italy, corporate groups controlled by family are quite common (Corbetta and Tomaselli, 1996; Cucculelli and Micucci, 2008), and more attention should be paid to this type of corporate group.

Finally, in our data, we have only the balance sheet data for Italian domestic firms 
but not for the foreign firms in these corporate groups. Additionally, existing studies control the average performance of all firms within a corporate group. ${ }^{11}$ We will add these group-level measures in the future once the data are available. Moreover, with the financial data on firms in other countries, we can also extend our analysis to the global scale and explore the difference in firm performance in different countries.

\subsection{Variables}

\subsubsection{Dependent Variable}

Sales growth is a widely used indicator of firm performance (Brush et al., 2000; Collins and Clark, 2003), which reflects how well an organization relates to the environment by successfully expanding its market scope (Ansoff, 1965; Dess and Robinson, 1984; Hofer and Schendel, 1978). We use the 3-year (2014-2016) average sales growth rate as the dependent variable. As a robustness check, we also use the logarithm of value added (VA) per labor or sales per labor as the dependent variable in the appendix.

\subsubsection{Independent Variables}

\section{Firm Centrality}

Given that the ownership network is directed, the firms that control no subsidiaries in a corporate group have no connecting path to other firms. Newman (2003) and Rochat (2009) have introduced harmonic centrality, which can avoid this problem by considering the reciprocal of the distance. The definition of the harmonic centrality of a node $i$ is

$$
c_{i}=\sum_{j} \frac{1}{d_{i j}}
$$

, where $d_{i j}$ is the number of links in a shortest path connecting node $i$ to node $j$. If node $i$ has no path to node $j$, their distance is considered infinity, and the reciprocal is thus zero. Therefore, a node that has no path to any other node in the network has a centrality value of zero.

We notice that nodes in a large component are prone to have larger harmonic centrality values. To reduce the effect of component size on centrality value, we provide a novel measure that normalizes the harmonic centrality to the interval $[0,1]$. By

\footnotetext{
${ }^{11}$ On the positive side, however, by focusing on a single country, we avoid comparing financial data across jurisdictions that are subject to different accounting rules.
} 
doing so, we make it more comparable when assessing how central a firm is across corporate groups of different sizes.

We define the normalized harmonic centrality as follows:

$$
n c_{i}=\frac{c_{i}-\min _{j \in g\left(n_{i}\right)}\left\{c_{j}\right\}}{\max _{j \in g\left(n_{i}\right)}\left\{c_{j}\right\}-\min _{j \in g\left(n_{i}\right)}\left\{c_{j}\right\}}
$$

where $n_{i}$ is the component size, that is, the number of nodes in the component to which node $i$ belongs. $g\left(n_{i}\right)$ is any component of size $n_{i}$. Given a component of size $n_{i}$, the largest possible value of centrality is reached when a node is directly connected to all the other $n_{i}-1$ nodes. In a directed graph ${ }^{12}$, the minimal centrality is obviously 0 , and formula 1 can be rewritten as

$$
n c_{i}=\frac{c_{i}}{n_{i}-1}
$$

In our case, $n_{i}$ is the number of firms in the corporate group to which firm $i$ belongs. Given a corporate group of size $n_{i}$, the largest possible value of centrality is reached when the ultimate owner directly controls all the $n_{i}-1$ subsidiaries. The comparison of harmonic and normalized centrality values of three examples is illustrated in Figure 2 and 3.

It should be noted that although our sample is restricted to Italian firms, $9.9 \%$ of these firms are in multinational groups. Because our centrality measure reflects a firm's position in the corporate group, the number of steps in the network between an Italian firm and a foreign firm in the same corporate group is also taken into account when computing the centrality.

Another (reverse) centrality measure of a firm is simply counting its distance from the ultimate owner (Belenzon et al., 2017). By analyzing the data on the structure of corporate groups in Western Europe, Belenzon et al. (2017) find that the focal subsidiaries with greater organizational distance from parent companies have

\footnotetext{
${ }^{12}$ We build the ownership network based on the control relationship among firms; thus, the direction of the ownership link is taken into account. If we ignore the direction and treat the network as an undirected one, the minimal possible centrality is reached when the component is a chain. The node at either end of the chain has the minimal centrality value, which is equal to $\sum_{k=1}^{n_{i}-1} \frac{1}{k}$. In this case, formula 1 can be rewritten as

$$
n c_{i}=\frac{c_{i}-\sum_{k=1}^{n_{i}-1} \frac{1}{k}}{n_{i}-1-\sum_{k=1}^{n_{i}-1} \frac{1}{k}}
$$
}




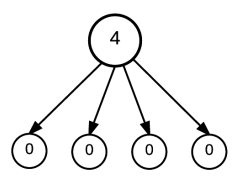

(a)

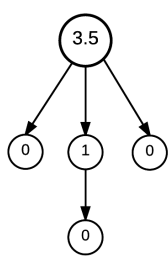

(b)

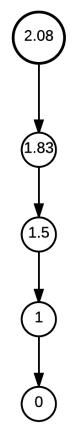

(c)
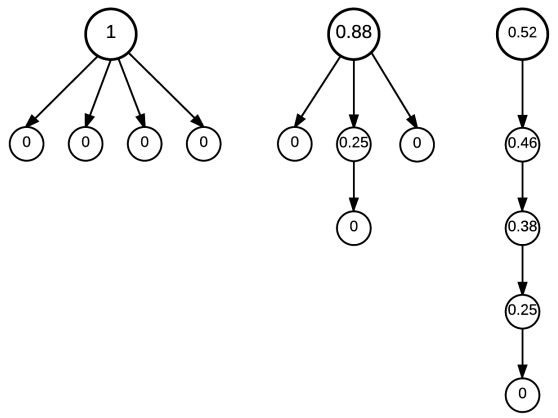

(a)

(b)

(c)

Figure 2: Original Harmonic Centrality Figure 3: Normalized Harmonic Centrality

lower sales growth rates and that their performance is more similar to that of the matched standalone firms in response to changing industry conditions. They call the simple measure the ownership level, which is defined as the number of intermediate subsidiaries separating a focal subsidiary from the parent company. ${ }^{13}$

\section{Corporate Group Size}

We take the number of firms in a corporate group to measure group size ${ }^{14}$ (Belenzon et al., 2017; Del Prete and Rungi, 2015). Because this measure has a long-tailed distribution, we perform a log transformation to reduce the variance. Another measure of corporate group size is the diameter of the network. Diameter is defined as the longest of all the shortest paths in a network, which in our case is a corporate group. For example, among all the shortest paths, the longest distances of the three prototypes in Figure 3 are 2, 3 and 4, respectively. Watts and Strogatz (1998) and Barabási and Albert (1999) argue that the diameter of a network increases logarithmically with the addition of new nodes. Hence, it can be viewed as a proxy for the logarithm of the number of firms in a corporate group.

\section{Control Variables}

\footnotetext{
${ }^{13}$ Belenzon et al. (2017) further add 1 to the number. They also replace the values of ownership levels larger than 6 with 6 .

${ }^{14}$ Because the ownership network of each corporate group identified by our algorithm may include the individual ultimate owner, the actual number of firms in a group can be 1 less than the number of nodes in its network. We make some further efforts to identify the possible individual ultimate owners. See the details in 6.4 in the appendix.
} 
The covariates include the firm-level factors in 2014, such as number of employees, capital intensity, firm age, whether the corporate group is multinational (mne dummy), dummies of sectors and regions in Italy. When we use the 3-year sales growth rate as the dependent variable, we also control the logarithm form of sales in 2014.

In addition, we use the pyramidal index (PI) introduced by Belenzon et al. (2013) as a control variable. The index reflects the extent to which the organization of subsidiaries is hierarchical by measuring the distribution of subsidiaries at different

ownership levels. They define the pyramidal index as $\frac{2\left(\sum_{i=1}^{N} i \times \text { share }_{i}-1\right)}{\# A f \text { iliates }^{-1}}$, where $N$ is the largest number of steps to the ultimate owner, share $_{i}$ is the ratio of the number of subsidiaries that are located at level $i$ to the total number of subsidiaries in the group, and \#Affiliates is the number of subsidiaries in the group. The value of PI varies from 0 to 1 . The higher value indicates that the group structure is more hierarchical. Aghion and Tirole (1997) argue that the hierarchical structures in which decision-making responsibility over non-routine tasks is delegated to local managers result in better decisions.

\subsection{Empirical Models}

We first explore the overall relationship between firm performance, firm centrality and group size through the following linear regression model:

$$
Y_{i}=\alpha+\beta_{1} \text { centrality }_{i}+\beta_{2} \log C G \text { size }_{j}+\boldsymbol{\gamma}^{\prime} \boldsymbol{Z}_{\boldsymbol{i}}+\epsilon_{i}
$$

where $Y_{i}$ is the performance of firm $i$, and $j$ is the corporate group to which firm $i$ belongs. $\mathbf{Z}_{i}$ are the aforementioned covariates. Because the performance of the firm within the same corporate group can be correlated, we relax the assumption of the independence of residuals. Instead, we use the cluster-robust standard errors in the estimation by controlling the component to which they belong.

Second, we examine the relationship between firm centrality and performance given group size. To guarantee that each subsample has enough observations, we merge some corporate groups of different sizes into few intervals. We run the regression model 2 separately over the subsamples, dropping the term $\log C G s_{s i e_{j}}$. 


\section{Results and Discussion}

We report the summary statistics of the variables in Table 3 and their correlation matrix in Table 4.

We then perform a linear regression model to explore the relationship between firm performance and the interaction of centrality and corporate group size. Table 5 reports the main regression results. ${ }^{15}$ First, note that the coefficient of the ownership level, as a simple measure of centrality, is significant and negative in the first three specifications. Correspondingly, the coefficient of our centrality measure is also significant and positive in all the specifications, controlling for the number of firms in the corporate group or diameter to measure group size, with or without the $\mathrm{PI}^{16}$ measure. The results show that both firm centrality and group size are generally positively correlated with sales growth. Table 8 and Table 10 in the appendix present the results using value added per labor and sales per labor as a performance measure, and the results are consistent. Note that the coefficients of other control variables such as the number of employees, capital intensity, firm age, and whether the corporate group is multinational all have the expected signs. Also note the high correlation between the two measures of corporate group size. As shown in Table 4, the correlation between the diameter and the logarithm form of the number of firms in the corporate group is as high as 0.946, which is in line with the theory in Watts and Strogatz (1998) and Barabási and Albert (1999).

In the following analysis, we use only our measure of centrality. Note that in the last specification, where we combine the ownership level and our measure, only ours remains significant. Compared with the ownership level, our centrality measure resolves the problem of its high collinearity with group size. It is also more informative because it takes into account the number of steps from a focal firm to all its direct and indirect controlling subsidiaries, which reflects to a certain extent the firmÕs coordinating power in the group's ownership network.

\footnotetext{
${ }^{15}$ All regression results are based on the majority control network. The results of the other two definitions of network are consistent and available upon request. In the regression model, the observations with the values of their dependent variable lying in the $1 \%$ tail of the distribution are excluded. We also conduct a robustness check by dropping the observations in the $5 \%$ tail of the distribution, and the results are similar and hence not reported here.

${ }^{16}$ The results in the rest of the paper are reduced to the sample of firms making part of groups of size larger than 2. On the one hand, the PI measure requires that the corporate groups have at least three companies. On the other hand, due to data restrictions, some groups of size 2 in our algorithm can be composed of an individual ultimate owner and a company. See 6.4 in the appendix for more details.
} 
We further explore the relationship between firm centrality and performance given the group size ${ }^{17}$. To guarantee that each subsample has enough observations, we divide the firms according to the following intervals of group size: $[3,5],[6,7],[8$, 13], $[14,50],[50,+\infty$. The results are shown in Table 6 . We notice that the coefficient of centrality is significant and positive when the component size is smaller than 6 . Table 9 and 11 in the appendix show the results using the other two performance measures. We find that when the corporate group size is larger than 7 , the coefficient of centrality is either not significant or sometimes even negative. The results imply that the centrality of Italian firms in the ownership network and their performance during the crisis are positively correlated if the corporate group size is smaller than 8.

\section{Conclusion}

In this paper, we have empirically investigated the relationship between the interaction of firm centrality and corporate group size and firm performance. Specifically, we have found a positive and significant relationship between firm centrality and performance for small corporate groups. However, the significance of the relationship decreases as the group size increases. Previous studies have found mixed results on the effects of firms' network positions for their economic and innovative performances (Kwon et al., 2016; Mani and Moody, 2014; Schilling and Phelps, 2007). That is, being central in the corporate network can be performance-enhancing because of the closeness to valuable resources (Owen-Smith and Powell, 2004; Powell et al., 1996; Soh, 2003; Tsai and Ghoshal, 1998) as well as performance-worsening because of the exposure to costs and risks (Uzzi, 1996, 1997). To help resolve the conflicting results, our study has identified corporate group size as an important dimension along which the positive effect of network centrality on firm performance varies. The findings suggest that there may exist a trade-off of performance for firms at central positions in large corporate groups. Though they can facilitate access to funds and information, they may face higher coordination costs and become more vulnerable to external shocks than if they were in small groups, which cancels out the positive effect. Therefore, efforts should be made to reduce the costs and risks induced by direct and indirect ownership links to retain the performance 'premium' of centrality in a corporate network.

Our contribution to the literature on the ownership network of corporate groups is

\footnotetext{
${ }^{17}$ Because the log number of firms is highly correlated with the diameter, we use only the former to measure corporate group size here and below.
} 
at least twofold. First, we provide a new measure of centrality. Considering that the ownership level measure used in Belenzon et al. (2017) has a high correlation with group size, we adopt the normalized harmonic centrality measure to neutralize the size effect. Consequently, we make centrality more comparable across groups of different sizes. Second, although the effects of individual-level centrality and grouplevel complexity on firm performance have been separately studied and discussed in the literature, the relationship between their interaction and firm performance is largely unclear. The practical issue might be the difficulty of disentangling the effect of centrality from that of corporate group size. As mentioned above, our normalized harmonic centrality measure is used in this paper to address the issue. By performing a detailed analysis with multiple robustness checks, we found that the relationship between firm centrality and firm performance depends on corporate group size.

Finally, the robustness of the results can be further tested after more data are collected across countries and over time. Some particularly interesting extensions include a replication study of another country with different institutional arrangements and corporate culture from Italy and a dynamic analysis before and after a significant economic event, such as the 2007-08 financial crisis. 


\section{References}

Aghion, P. and J. Tirole (1997). Formal and real authority in organizations. Journal of political economy 105(1), 1-29.

Ahuja, G. (2000). Collaboration networks, structural holes, and innovation: A longitudinal study. Administrative science quarterly 45(3), 425-455.

Almeida, H. V. and D. Wolfenzon (2006). A theory of pyramidal ownership and family business groups. The Journal of Finance 61 (6), 2637-2680.

Altomonte, C. and A. Rungi (2013). Business groups as hierarchies of firms: determinants of vertical integration and performance.

Ansoff, H. I. (1965). Corporate strategy: business policy for growth and expansion. McGraw-Hill Book.

Barabási, A.-L. and R. Albert (1999). Emergence of scaling in random networks. science 286(5439), 509-512.

Belenzon, S. and T. Berkovitz (2010). Innovation in business groups. Management Science 56(3), 519-535.

Belenzon, S., N. Hashai, and A. Patacconi (2017). The architecture of attention: Group structure and subsidiary autonomy.

Belenzon, S., A. Patacconi, and B. Zelner (2013). The nebulous nature of the firm: An empirical study of corporate group structure in 16 developed economies.

Bernstein, J. I. and P. Mohnen (1998). International r\&d spillovers between us and japanese r\&d intensive sectors. Journal of international economics 44 (2), 315-338.

Bethel, J. E. and J. P. Liebeskind (1998). Diversification and the legal organization of the firm. Organization Science 9(1), 49-67.

Blomström, M. and F. Sjöholm (1999). Technology transfer and spillovers: does local participation with multinationals matter? European economic review 43(4), 915-923.

Borgatti, S. P. and D. S. Halgin (2011). On network theory. Organization science 22(5), 1168-1181.

Brush, T. H., P. Bromiley, and M. Hendrickx (2000). The free cash flow hypothesis for sales growth and firm performance. Strategic Management Journal, 455-472. 
Cainelli, G. and D. Iacobucci (2011). Business groups and the boundaries of the firm. Management Decision 49(9), 1549-1573.

Cainelli, G., D. Iacobucci, and E. Morganti (2006). Spatial agglomeration and business groups: new evidence from italian industrial districts. Regional Studies 40(5), $507-518$.

Caliendo, L. and E. Rossi-Hansberg (2012). The impact of trade on organization and productivity. The quarterly journal of economics 127(3), 1393-1467.

Carpenter, M. A., M. Li, and H. Jiang (2012). Social network research in organizational contexts: A systematic review of methodological issues and choices. Journal of Management 38(4), 1328-1361.

Collins, C. J. and K. D. Clark (2003). Strategic human resource practices, top management team social networks, and firm performance: The role of human resource practices in creating organizational competitive advantage. Academy of management Journal 46(6), 740-751.

Corbetta, G. and S. Tomaselli (1996). Boards of directors in italian family businesses. Family Business Review 9(4), 403-421.

Cucculelli, M. and G. Micucci (2008). Family succession and firm performance: Evidence from italian family firms. Journal of Corporate Finance 14(1), 17-31.

Del Prete, D. and A. Rungi (2015). Organizing the global value chain: a firm-level test.

Dess, G. G. and R. B. Robinson (1984). Measuring organizational performance in the absence of objective measures: the case of the privately-held firm and conglomerate business unit. Strategic management journal 5(3), 265-273.

Freeman, L. C. (1978). Centrality in social networks conceptual clarification. Social networks 1(3), 215-239.

Glattfelder, J. B. (2010). Ownership networks and corporate control.

Goto, A. (1982). Business groups in a market economy. European economic review 19(1), 53-70.

Gulati, R. and M. Gargiulo (1999). Where do interorganizational networks come from? 1. American journal of sociology 104 (5), 1439-1493.

Gulati, R., N. Nohria, and A. Zaheer (2000). Strategic networks. Strategic management journal, 203-215. 
Hofer, C. W. and D. Schendel (1978). Strategy formulation: Analytical concepts. West Publ.

Kali, R. and J. Sarkar (2011). Diversification and tunneling: Evidence from indian business groups. Journal of Comparative Economics 39(3), 349-367.

Khanna, T. and K. Palepu (2000). Is group affiliation profitable in emerging markets? an analysis of diversified indian business groups. The Journal of Finance 55(2), 867-891.

Kostić, Z. (2013). Mergers and acquisitions during the economic-financial crisis.

Kwon, S.-W., J. Haleblian, J. Hagedoorn, et al. (2016). In country we trust? national trust and the governance of international $\mathrm{r} \& d$ alliances. Journal of International Business Studies 47(7), 807-829.

La Porta, R., F. Lopez-de Silanes, A. Shleifer, and R. W. Vishny (1997). Legal determinants of external finance. Journal of finance, 1131-1150.

La Porta, R., F. Lopez-de Silanes, A. Shleifer, and R. W. Vishny (1998). Law and finance. Journal of political economy 106(6), 1113-1155.

Mahmood, I. P., H. Zhu, and A. Zaheer (2017). Centralization of intragroup equity ties and performance of business group affiliates. Strategic Management Journal 38(5), 1082-1100.

Mani, D. and J. Moody (2014). Moving beyond stylized economic network models: The hybrid world of the indian firm ownership network 1. American Journal of Sociology 119(6), 1629-1669.

Markusen, J. R. (1995). The boundaries of multinational enterprises and the theory of international trade. The Journal of Economic Perspectives 9(2), 169-189.

McGowan, M. A., D. Andrews, V. Millot, et al. (2017). The walking dead?: Zombie firms and productivity performance in oecd countries. Technical report, OECD Publishing.

Newman, M. E. (2003). The structure and function of complex networks. SIAM review 45(2), 167-256.

Owen-Smith, J. and W. W. Powell (2004). Knowledge networks as channels and conduits: The effects of spillovers in the boston biotechnology community. Organization science 15(1), 5-21. 
Patacconi, A. (2009). Coordination and delay in hierarchies. The RAND Journal of Economics 40(1), 190-208.

Peterson, M. and R. Rajan (1994). The benefits of lending relationships: Evidence from small business data. Journal of Finance 49(1), 3-37.

Powell, W. W., K. W. Koput, and L. Smith-Doerr (1996). Interorganizational collaboration and the locus of innovation: Networks of learning in biotechnology. Administrative science quarterly, 116-145.

Powell, W. W., K. W. Koput, L. Smith-Doerr, and J. Owen-Smith (1999). Network position and firm performance: Organizational returns to collaboration in the biotechnology industry. Research in the Sociology of Organizations 16(1), 129159 .

Provan, K. G., A. Fish, and J. Sydow (2007). Interorganizational networks at the network level: A review of the empirical literature on whole networks. Journal of management 33(3), 479-516.

Rochat, Y. (2009). Closeness centrality extended to unconnected graphs: The harmonic centrality index. In ASNA, Number EPFL-CONF-200525.

Schilling, M. A. and C. C. Phelps (2007). Interfirm collaboration networks: The impact of large-scale network structure on firm innovation. Management Science 53(7), 1113-1126.

Soh, P.-H. (2003). The role of networking alliances in information acquisition and its implications for new product performance. Journal of Business Venturing 18(6), $727-744$.

Tsai, W. (2001). Knowledge transfer in intraorganizational networks: Effects of network position and absorptive capacity on business unit innovation and performance. Academy of management journal 44(5), 996-1004.

Tsai, W. and S. Ghoshal (1998). Social capital and value creation: The role of intrafirm networks. Academy of management Journal 41(4), 464-476.

UNCTAD (2016). World investment report 2016. investor nationality: Policy challenges.

Uzzi, B. (1996). The sources and consequences of embeddedness for the economic performance of organizations: The network effect. American sociological review, 674-698. 
Uzzi, B. (1997). Social structure and competition in interfirm networks: The paradox of embeddedness. Administrative science quarterly, 35-67.

Vasconcelos, F. C. and R. Ramirez (2011). Complexity in business environments. Journal of Business Research 64(3), 236-241.

Vitali, S. and S. Battiston (2011). Geography versus topology in the european ownership network. New Journal of Physics 13(6), 063021.

Vitali, S., J. B. Glattfelder, and S. Battiston (2011). The network of global corporate control. PloS one 6(10), e25995.

Watts, D. J. and S. H. Strogatz (1998). Collective dynamics of 'small-world' networks. nature 393(6684), 440-442.

Zaheer, A. and G. G. Bell (2005). Benefiting from network position: firm capabilities, structural holes, and performance. Strategic management journal 26 (9), 809-825. 
Table 1: Example of the Data

\begin{tabular}{cccc}
\hline mark & firm & direct owner & ownership shares \\
\hline 1 & B & A & $100 \%$ \\
2 & C & B & $100 \%$ \\
3 & D & A & $97 \%$ \\
4 & E & A & $79.35 \%$ \\
5 & E & K & $20.65 \%$ \\
6 & F & E & $95 \%$ \\
7 & G & F & $100 \%$ \\
8 & H & F & $90 \%$ \\
9 & H & L & $10 \%$ \\
10 & I & H & $100 \%$ \\
11 & J & A & $100 \%$ \\
\hline
\end{tabular}

Table 2: Distribution of Direct Ownership Share

\begin{tabular}{rcc}
\hline ownership share & frequency & percentage \\
\hline$(0,25 \%]$ & $3,997,584$ & $15.59 \%$ \\
$(25 \%, 50 \%]$ & $7,144,627$ & $27.87 \%$ \\
$(50 \%, 75 \%]$ & $3,615,425$ & $14.10 \%$ \\
$(75 \%, 100 \%]$ & $10,877,504$ & $42.43 \%$ \\
\hline Total & $25,635,140$ & $100.00 \%$ \\
\hline
\end{tabular}


Table 3: Summary Statistics

\begin{tabular}{lcccccc}
\hline Variables & $\mathrm{N}$ & mean & $\mathrm{sd}$ & $\mathrm{p} 10$ & $\mathrm{p} 50$ & $\mathrm{p} 90$ \\
\hline centrality & 483,835 & 0.0628 & 0.215 & 0 & 0 & 0 \\
ownership level & 483,831 & 1.098 & 0.535 & 1 & 1 & 2 \\
No. employees 2014 & 395,395 & 14.15 & 167.1 & 1 & 3 & 18 \\
No. firms in CG & 483,835 & 14.53 & 109.0 & 2 & 2 & 6 \\
diameter & 483,835 & 1.674 & 1.592 & 1 & 1 & 3 \\
PI & 159,883 & 0.228 & 0.341 & 0 & 0.0105 & 1 \\
fixed assets 2014 & 396,357 & 1,641 & 79,799 & 0 & 33 & 1,554 \\
capital intensity 2014 & 395,025 & 370.7 & 5,675 & 0 & 7.250 & 438 \\
age & 483,751 & 14.27 & 12.39 & 3 & 10 & 31 \\
mne & 483,835 & 0.0987 & 0.298 & 0 & 0 & 0 \\
value added 2014 & 396,730 & 912.9 & 21,688 & -7 & 67 & 897 \\
VA per labor 2014 & 395,395 & 45.26 & 700.0 & -5.069 & 22.20 & 80 \\
sales 2014 & 396,590 & 4,265 & 111,372 & 0 & 256 & 3,630 \\
sales per labor 2014 & 395,255 & 229.6 & 2,304 & 0 & 76 & 380 \\
3-year (2014-2016) sales growth rate & 228,168 & 0.373 & 9.393 & -0.212 & 0.0254 & 0.399 \\
\hline
\end{tabular}


Table 4: Correlation Matrix

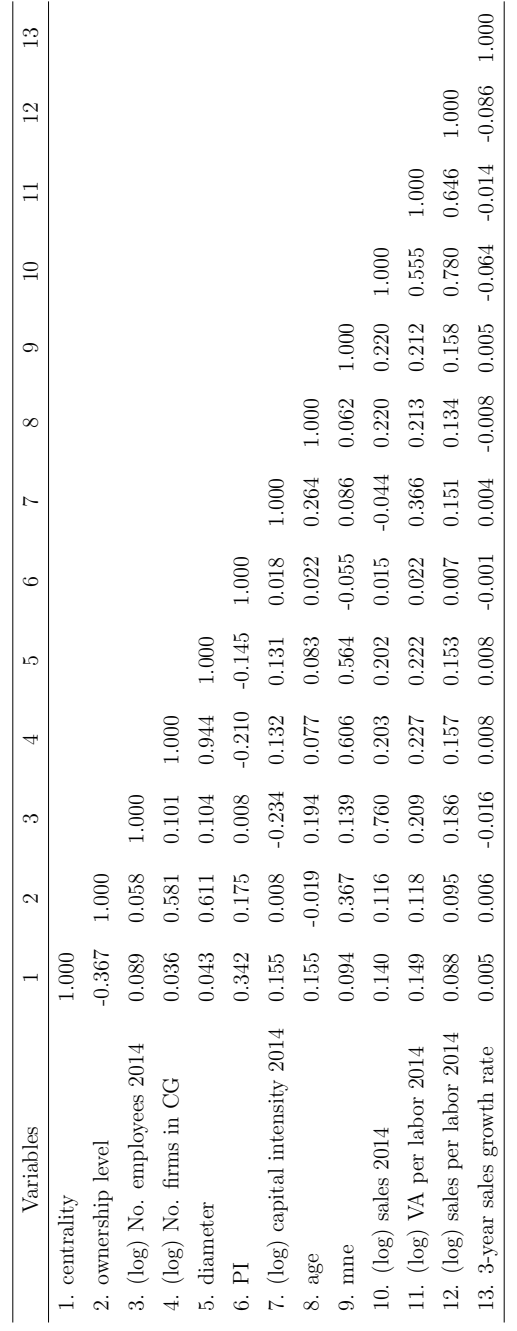


Table 5: Regression Results of Centrality and Corporate Group Size

\begin{tabular}{|c|c|c|c|c|c|c|c|}
\hline \multicolumn{8}{|c|}{ Dependent variable: 3 -year average sales growth rate } \\
\hline & (1) & $(2)$ & $(3)$ & $(4)$ & $(5)$ & (6) & (7) \\
\hline VARIABLES & Sales growth & Sales growth & Sales growth & Sales growth & Sales growth & Sales growth & Sales growth \\
\hline \multirow[t]{2}{*}{ ownership level } & $-0.00812^{* * *}$ & $-0.00493^{*}$ & $-0.00446^{*}$ & & & & 0.00451 \\
\hline & $(0.00251)$ & $(0.00255)$ & $(0.00266)$ & & & & $(0.00293)$ \\
\hline \multirow[t]{2}{*}{ centrality } & & & & $0.0556^{* * *}$ & $0.0450^{* * *}$ & $0.0443^{* * *}$ & $0.0507^{* * * *}$ \\
\hline & & & & $(0.00451)$ & $(0.00728)$ & $(0.00727)$ & $(0.00832)$ \\
\hline \multirow[t]{2}{*}{$(\log )$ No. firms } & $0.0124^{* * *}$ & $0.00565^{*}$ & & $0.0111^{* * *}$ & $0.00533^{* *}$ & & \\
\hline & $(0.00314)$ & $(0.00308)$ & & $(0.00248)$ & $(0.00262)$ & & \\
\hline \multirow[t]{2}{*}{ PI } & & $0.0178^{* * *}$ & $0.0157^{* * *}$ & & 0.00418 & 0.00255 & -0.00166 \\
\hline & & $(0.00540)$ & $(0.00521)$ & & $(0.00522)$ & $(0.00516)$ & $(0.00586)$ \\
\hline \multirow[t]{2}{*}{ diameter } & & & 0.00225 & & & $0.00210^{*}$ & 0.00120 \\
\hline & & & $(0.00145)$ & & & $(0.00118)$ & $(0.00136)$ \\
\hline \multirow[t]{2}{*}{ (log) No. employees } & $0.0471^{* * *}$ & $0.0412^{* * *}$ & $0.0412^{* * *}$ & $0.0462^{* * *}$ & $0.0403^{* * *}$ & $0.0403^{* * *}$ & $0.0403^{* * *}$ \\
\hline & $(0.00145)$ & $(0.00227)$ & $(0.00227)$ & $(0.00144)$ & $(0.00227)$ & $(0.00227)$ & $(0.00227)$ \\
\hline \multirow[t]{2}{*}{ (log) capital intensity } & $0.00521^{* * *}$ & $0.00406^{* * *}$ & $0.00409^{* * *}$ & $0.00454^{* * *}$ & $0.00346^{* * *}$ & $0.00350^{* * *}$ & $0.00351^{* * *}$ \\
\hline & $(0.000544)$ & $(0.000904)$ & $(0.000905)$ & $(0.000544)$ & $(0.000907)$ & $(0.000908)$ & $(0.000909)$ \\
\hline \multirow[t]{2}{*}{$(\log )$ sales 2014} & $-0.0595^{* * *}$ & $-0.0530^{* * *}$ & $-0.0530^{* * *}$ & $-0.0604 * * *$ & $-0.0535^{* * *}$ & $-0.0534^{* * *}$ & $-0.0535 * * *$ \\
\hline & $(0.00130)$ & $(0.00207)$ & $(0.00206)$ & $(0.00131)$ & $(0.00207)$ & $(0.00207)$ & $(0.00207)$ \\
\hline \multirow[t]{2}{*}{ mne } & $0.0398^{* * *}$ & $0.0288^{* * *}$ & $0.0319^{* * *}$ & $0.0345^{* * *}$ & $0.0254^{* * *}$ & $0.0287^{* * * *}$ & $0.0279^{* * *}$ \\
\hline & $(0.00414)$ & $(0.00502)$ & $(0.00470)$ & $(0.00415)$ & $(0.00508)$ & $(0.00475)$ & $(0.00477)$ \\
\hline \multirow[t]{2}{*}{ age } & $-0.00160^{* * *}$ & $-0.00115^{* * *}$ & $-0.00115^{* * *}$ & $-0.00168^{* * *}$ & $-0.00121 * * *$ & $-0.00122^{* * *}$ & $-0.00121^{* * *}$ \\
\hline & $(8.04 \mathrm{e}-05)$ & $(0.000133)$ & $(0.000132)$ & $(8.16 \mathrm{e}-05)$ & $(0.000135)$ & $(0.000135)$ & $(0.000135)$ \\
\hline sectors & Yes & Yes & Yes & Yes & Yes & Yes & Yes \\
\hline regions & Yes & Yes & Yes & Yes & Yes & Yes & Yes \\
\hline \multirow[t]{2}{*}{ Constant } & $0.407 * * *$ & $0.379 * * *$ & $0.381 * * *$ & $0.408^{* * *}$ & $0.381 * * *$ & $0.384^{* * *}$ & $0.381^{* * *}$ \\
\hline & $(0.00722)$ & $(0.0127)$ & $(0.0128)$ & $(0.00699)$ & $(0.0127)$ & $(0.0127)$ & $(0.0128)$ \\
\hline Observations & 225,717 & 72,127 & 72,127 & 225,721 & 72,127 & 72,127 & 72,127 \\
\hline R-squared & 0.035 & 0.029 & 0.029 & 0.035 & 0.030 & 0.030 & 0.030 \\
\hline
\end{tabular}


Table 6: Regression Results of Subsamples by Corporate Group Sizes

\begin{tabular}{|c|c|c|c|c|c|}
\hline \multicolumn{6}{|c|}{ Dependent variable: 3 -year average sales growth rate } \\
\hline & (1) & $(2)$ & $(3)$ & (4) & (5) \\
\hline VARIABLES & Size $3-5$ & Size 6-7 & Size 8-13 & Size $14-50$ & Size $50+$ \\
\hline \multirow[t]{2}{*}{ centrality } & $0.0625^{* * *}$ & -0.0194 & 0.0403 & 0.0383 & 0.00221 \\
\hline & $(0.00890)$ & $(0.0178)$ & $(0.0247)$ & $(0.0278)$ & $(0.0456)$ \\
\hline \multirow[t]{2}{*}{ PI } & 0.00488 & -0.00987 & -0.00342 & -0.0325 & 0.342 \\
\hline & $(0.00546)$ & $(0.0313)$ & $(0.0397)$ & $(0.0751)$ & $(0.253)$ \\
\hline \multirow[t]{2}{*}{ (log) No. employees } & $0.0417^{* * *}$ & $0.0413^{* * *}$ & $0.0307^{* * *}$ & $0.0266^{* * *}$ & $0.0397^{* * *}$ \\
\hline & $(0.00304)$ & $(0.00716)$ & $(0.00754)$ & $(0.00707)$ & $(0.00567)$ \\
\hline \multirow[t]{2}{*}{ (log) capital intensity } & $0.00291^{* *}$ & $0.00828^{* * *}$ & 0.00233 & 0.00396 & 0.00336 \\
\hline & $(0.00117)$ & $(0.00282)$ & $(0.00287)$ & $(0.00291)$ & $(0.00244)$ \\
\hline \multirow[t]{2}{*}{$(\log )$ sales 2014} & $-0.0598^{* * *}$ & $-0.0457 * * *$ & $-0.0435^{* * *}$ & $-0.0407 * * *$ & $-0.0448 * * *$ \\
\hline & $(0.00268)$ & $(0.00627)$ & $(0.00697)$ & $(0.00717)$ & $(0.00562)$ \\
\hline \multirow[t]{2}{*}{ age } & $-0.00148^{* * *}$ & $-0.000633^{*}$ & $-0.000839^{*}$ & $-0.000821^{* *}$ & $-0.000771^{*}$ \\
\hline & $(0.000145)$ & $(0.000374)$ & $(0.000458)$ & $(0.000339)$ & $(0.000434)$ \\
\hline \multirow[t]{2}{*}{ mne } & $0.0240^{* * *}$ & 0.0189 & -0.0106 & $0.0372^{* *}$ & $0.0944^{* * *}$ \\
\hline & $(0.00700)$ & $(0.0131)$ & $(0.0128)$ & $(0.0160)$ & $(0.0201)$ \\
\hline sectors & Yes & Yes & Yes & Yes & Yes \\
\hline regions & Yes & Yes & Yes & Yes & Yes \\
\hline \multirow[t]{2}{*}{ Constant } & $0.436^{* * *}$ & $0.305^{* * *}$ & $0.326^{* * *}$ & $0.308^{* * *}$ & $0.210^{* * *}$ \\
\hline & $(0.0162)$ & $(0.0400)$ & $(0.0441)$ & $(0.0518)$ & $(0.0417)$ \\
\hline Observations & 49,058 & 5,745 & 5,698 & 6,003 & 5,623 \\
\hline R-squared & 0.035 & 0.026 & 0.023 & 0.023 & 0.028 \\
\hline
\end{tabular}

Robust standard errors in parentheses

*** $\mathrm{p}<0.01,{ }^{* *} \mathrm{p}<0.05,{ }^{*} \mathrm{p}<0.1$ 


\section{Appendix}

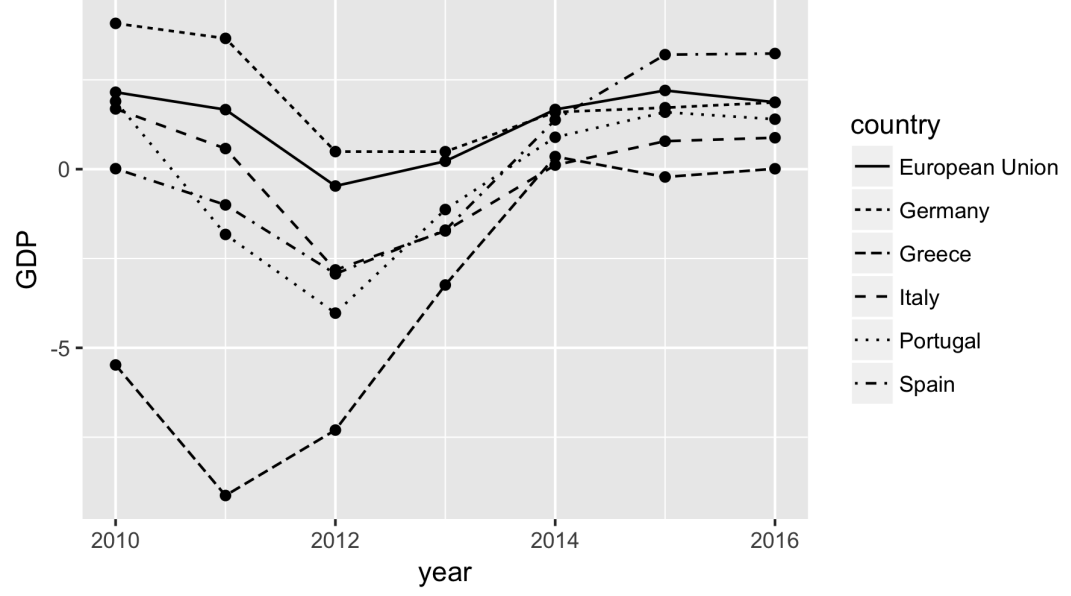

Figure 4: Real GDP Growth Rate of Some European Countries

\subsection{Variables Definitions}




\section{Table 7: Variables Definitions}

\begin{tabular}{|c|c|}
\hline Variables & Definition \\
\hline 3-year sales growth rate & $\left(\sum_{i=2014}^{2015}\left(\right.\right.$ sales $_{i+1}-$ sales $\left._{i}\right) /$ sales $\left._{i}\right) / 2$. \\
\hline centrality & A measure of firm's centrality in a corporate group. \\
\hline CG size & The number of firms that belong to a corporate group. \\
\hline diameter & The longest of all the shortest paths in a network. \\
\hline VA per labor & value added/No. employees in 2014. \\
\hline sales per labor & sales/No. employees in 2014. \\
\hline capital intensity & fixed assets/No. employees in 2014. \\
\hline mne & A dummy variable equal to 1 if a firm belongs to a multinational group, and 0 otherwise. \\
\hline ownership level & The number of subsidiaries separating a focal subsidiary from the parent company. \\
\hline PI & The pyramidal index defined by Belenzon et al. (2013). \\
\hline sectors & $\begin{array}{l}\text { A set of dummy variables that equal } 1 \text { if a firm belongs to a certain sector, and } \\
\text { sector } 4 \text { is used as a benchmark in the regression. } \\
\text { 1: Agriculture, forestry and fishing. } \\
\text { 2: Manufacturing, mining and quarrying and other industry. } \\
\text { 3: Construction. } \\
\text { 4: Wholesale and retail trade, transportation and storage, accommodation and } \\
\text { food service activities. } \\
\text { 5: Information and communication. } \\
\text { 6: Financial and insurance activities. } \\
\text { 7: Real estate activities (including imputed rents of owner-occupied dwellings). } \\
\text { 8: Professional, scientific, technical, administration and support service activities. } \\
\text { 9: Public administration, defense, education, human health and social work activities. } \\
\text { 10: Other services. }\end{array}$ \\
\hline regions & $\begin{array}{l}\text { A set of dummy variables that takes a value of } 1 \text { if a firm belongs to a } \\
\text { certain region and region } 2 \text { is used as benchmark in the regression. } \\
\text { 1: NordOvest. } \\
\text { 2: NordEst. } \\
\text { 3: Centro. } \\
\text { 4: Mezzogiorno. }\end{array}$ \\
\hline
\end{tabular}




\subsection{Robustness Check 1: Using Value Added per labor as the Dependent Variable}

Table 8: Regression Results of Centrality and Different CG Size Measures Dependent variable: log VA per labor

\begin{tabular}{|c|c|c|c|c|}
\hline VARIABLES & $(1)$ & $(2)$ & (3) & (4) \\
\hline centrality & $\begin{array}{l}0.244^{* * *} \\
(0.00855)\end{array}$ & $\begin{array}{l}0.239^{* * *} \\
(0.00863)\end{array}$ & $\begin{array}{c}0.114^{* * *} \\
(0.0142)\end{array}$ & $\begin{array}{c}0.111^{* * *} \\
(0.0143)\end{array}$ \\
\hline$(\log )$ No. firms & $\begin{array}{c}0.104^{* * *} \\
(0.0135)\end{array}$ & & $\begin{array}{c}0.0552^{\text {*** }} \\
(0.0149)\end{array}$ & \\
\hline diameter & & $\begin{array}{c}0.0529 * * * \\
(0.00681)\end{array}$ & & $\begin{array}{c}0.0247^{* * *} \\
(0.00687)\end{array}$ \\
\hline PI & & & $\begin{array}{c}0.0747^{* * *} \\
(0.0106)\end{array}$ & $\begin{array}{c}0.0603^{* * *} \\
(0.0103)\end{array}$ \\
\hline (log) No. employees & $\begin{array}{l}0.188^{* * *} \\
(0.00247)\end{array}$ & $\begin{array}{c}0.188^{* * *} \\
(0.00238)\end{array}$ & $\begin{array}{l}0.126^{* * *} \\
(0.00385)\end{array}$ & $\begin{array}{l}0.126^{* * *} \\
(0.00373)\end{array}$ \\
\hline (log) capital intensity & $\begin{array}{c}0.157^{* * *} \\
(0.00105)\end{array}$ & $\begin{array}{c}0.157^{* * *} \\
(0.00105)\end{array}$ & $\begin{array}{l}0.152^{* * *} \\
(0.00187)\end{array}$ & $\begin{array}{c}0.153^{* * *} \\
(0.00186)\end{array}$ \\
\hline age & $\begin{array}{c}0.00303^{* * *} \\
(0.000168)\end{array}$ & $\begin{array}{c}0.00301^{* * *} \\
(0.000168)\end{array}$ & $\begin{array}{c}0.00153^{* * *} \\
(0.000273)\end{array}$ & $\begin{array}{c}0.00149^{* * *} \\
(0.000272)\end{array}$ \\
\hline mne & $\begin{array}{c}0.151^{* * *} \\
(0.0119)\end{array}$ & $\begin{array}{c}0.180^{* * *} \\
(0.0108)\end{array}$ & $\begin{array}{c}0.195^{* * *} \\
(0.0150)\end{array}$ & $\begin{array}{c}0.223^{* * *} \\
(0.0130)\end{array}$ \\
\hline sectors & Yes & Yes & Yes & Yes \\
\hline regions & Yes & Yes & Yes & Yes \\
\hline Constant & $\begin{array}{l}2.254^{* * *} \\
(0.00985)\end{array}$ & $\begin{array}{l}2.273^{* * *} \\
(0.00806)\end{array}$ & $\begin{array}{c}2.556^{* * *} \\
(0.0211)\end{array}$ & $\begin{array}{c}2.578^{* * *} \\
(0.0178)\end{array}$ \\
\hline Observations & 285,303 & 285,303 & 88,065 & 88,065 \\
\hline R-squared & 0.239 & 0.238 & 0.199 & 0.199 \\
\hline
\end{tabular}

Robust standard errors in parentheses

$$
\text { *** } \mathrm{p}<0.01,{ }^{* *} \mathrm{p}<0.05,{ }^{*} \mathrm{p}<0.1
$$


Table 9: Regression Results of Subsamples by Corporate Group Sizes

\begin{tabular}{lccccc}
\hline \multicolumn{5}{c}{ Dependent variable: $(\mathrm{log})$ VA per labor } \\
\hline \multirow{2}{*}{ VARIABLES } & $(1)$ & $(2)$ & $(3)$ & $(4)$ & $(5)$ \\
& CG size 3-5 & CG size 6-7 & CG size 8-13 & CG size 14-50 & CG size 50+ \\
\hline \multirow{2}{*}{ centrality } & & & & & \\
& $0.156^{* * *}$ & $0.150^{* * *}$ & -0.0687 & -0.0516 & $-0.239^{*}$ \\
PI & $(0.0159)$ & $(0.0432)$ & $(0.0485)$ & $(0.0568)$ & $(0.122)$ \\
& $0.0655^{* * *}$ & 0.0856 & 0.00947 & 0.305 & $3.283^{* * *}$ \\
(log) No. employees & $(0.0106)$ & $(0.0655)$ & $(0.0935)$ & $(0.207)$ & $(0.870)$ \\
& $0.163^{* * *}$ & $0.0688^{* * *}$ & $0.0450^{* * *}$ & $0.0286^{* * *}$ & $0.119^{* * *}$ \\
(log) capital intensity & $(0.00360)$ & $(0.00917)$ & $(0.00935)$ & $(0.0103)$ & $(0.0121)$ \\
& $0.163^{* * *}$ & $0.148^{* * *}$ & $0.139^{* * *}$ & $0.129^{* * *}$ & $0.112^{* * *}$ \\
age & $(0.00206)$ & $(0.00606)$ & $(0.00630)$ & $(0.00673)$ & $(0.0100)$ \\
& $0.00175^{* * *}$ & 0.000838 & -0.000332 & $0.00153^{*}$ & $0.00338^{* * *}$ \\
mne & $(0.000305)$ & $(0.000811)$ & $(0.000599)$ & $(0.000846)$ & $(0.000956)$ \\
& $0.128^{* * *}$ & $0.154^{* * *}$ & $0.194^{* * *}$ & $0.209^{* * *}$ & $0.391^{* * *}$ \\
sectors & $(0.0145)$ & $(0.0299)$ & $(0.0290)$ & $(0.0520)$ & $(0.121)$ \\
regions & Yes & Yes & Yes & Yes & Yes \\
Constant & Yes & Yes & Yes & Yes & Yes \\
Observations & $2.486^{* * *}$ & $2.922^{* * *}$ & $3.118^{* * *}$ & $3.281^{* * *}$ & $2.745^{* * *}$ \\
\hline & $(0.0142)$ & $(0.0504)$ & $(0.0580)$ & $(0.0828)$ & $(0.143)$ \\
& 61,742 & 6,905 & 6,621 & 6,555 & 6,242 \\
& 0.194 & 0.179 & 0.166 & 0.146 & 0.154 \\
\hline
\end{tabular}

Robust standard errors in parentheses *** $\mathrm{p}<0.01,{ }^{* *} \mathrm{p}<0.05,{ }^{*} \mathrm{p}<0.1$ 


\subsection{Robustness Check 2: Using Sales per labor as Depen- dent Variable}

Table 10: Regression Results of Centrality and Different CG Size Measures

\begin{tabular}{|c|c|c|c|c|}
\hline \multicolumn{5}{|c|}{ Dependent variable: log sales per labor } \\
\hline VARIABLES & $(1)$ & $(2)$ & $(3)$ & $(4)$ \\
\hline \multirow[t]{2}{*}{ centrality } & $0.284^{* * *}$ & $0.280^{* * *}$ & $0.147^{* * *}$ & $0.145^{* * *}$ \\
\hline & $(0.0103)$ & $(0.0103)$ & $(0.0166)$ & $(0.0167)$ \\
\hline \multirow[t]{2}{*}{$(\log )$ No. firms } & $0.0964^{* * *}$ & & $0.0473^{* * *}$ & \\
\hline & $(0.0128)$ & & $(0.0124)$ & \\
\hline \multirow[t]{2}{*}{ diameter } & & $0.0499^{* * *}$ & & $0.0218^{* * *}$ \\
\hline & & $(0.00663)$ & & $(0.00581)$ \\
\hline \multirow[t]{2}{*}{ PI } & & & $0.0497^{* * *}$ & $0.0372^{* * *}$ \\
\hline & & & $(0.0125)$ & $(0.0123)$ \\
\hline \multirow[t]{2}{*}{$(\log )$ No. employees } & $0.110^{* * *}$ & $0.110^{* * *}$ & $0.124^{* * *}$ & $0.124^{* * *}$ \\
\hline & $(0.00271)$ & $(0.00268)$ & $(0.00405)$ & $(0.00400)$ \\
\hline \multirow[t]{2}{*}{ (log) capital intensity } & $0.0985^{* * *}$ & $0.0987^{* * *}$ & $0.100^{* * *}$ & $0.100^{* * *}$ \\
\hline & $(0.00121)$ & $(0.00120)$ & $(0.00211)$ & $(0.00211)$ \\
\hline \multirow[t]{2}{*}{ age } & $0.00330^{* * *}$ & $0.00327^{* * *}$ & $0.00189^{* * *}$ & $0.00185^{* * *}$ \\
\hline & $(0.000191)$ & $(0.000191)$ & $(0.000325)$ & $(0.000324)$ \\
\hline \multirow[t]{2}{*}{ mne } & $0.201^{* * *}$ & $0.226^{* * *}$ & $0.221^{* * *}$ & $0.243^{* * *}$ \\
\hline & $(0.0127)$ & $(0.0118)$ & $(0.0159)$ & $(0.0140)$ \\
\hline sectors & Yes & Yes & Yes & Yes \\
\hline regions & Yes & Yes & Yes & Yes \\
\hline \multirow[t]{2}{*}{ Constant } & $4.064^{* * *}$ & $4.081^{* * *}$ & $4.147^{* * *}$ & $4.164^{* * *}$ \\
\hline & $(0.00992)$ & $(0.00851)$ & $(0.0215)$ & $(0.0193)$ \\
\hline Observations & 305,117 & 305,117 & 94,761 & 94,761 \\
\hline R-squared & 0.158 & 0.157 & 0.151 & 0.150 \\
\hline
\end{tabular}

Robust standard errors in parentheses

*** $\mathrm{p}<0.01, * * \mathrm{p}<0.05,{ }^{*} \mathrm{p}<0.1$ 
Table 11: Regression Results of Subsamples by Corporate Group Sizes Dependent variable: $(\log )$ sales per labor

\begin{tabular}{lccccc}
\hline & $(1)$ & $(2)$ & $(3)$ & $(4)$ & $(5)$ \\
VARIABLES & Size $3-5$ & Size 6-7 & Size 8-13 & Size 14-50 & Size 50+ \\
\hline centrality & $0.181^{* * *}$ & $0.165^{* * *}$ & 0.0195 & 0.0436 & $-0.279^{*}$ \\
& $(0.0193)$ & $(0.0509)$ & $(0.0530)$ & $(0.0679)$ & $(0.159)$ \\
PI & $0.0475^{* * *}$ & -0.00566 & -0.0269 & 0.107 & $4.374^{* * *}$ \\
& $(0.0128)$ & $(0.0793)$ & $(0.116)$ & $(0.235)$ & $(0.971)$ \\
(log) No. employees & $0.147^{* * *}$ & $0.0989^{* * *}$ & $0.0722^{* * *}$ & $0.0631^{* * *}$ & $0.118^{* * *}$ \\
& $(0.00447)$ & $(0.0116)$ & $(0.0113)$ & $(0.0115)$ & $(0.0123)$ \\
(log) capital intensity & $0.101^{* * *}$ & $0.100^{* * *}$ & $0.0850^{* * *}$ & $0.0830^{* * *}$ & $0.104^{* * *}$ \\
& $(0.00242)$ & $(0.00699)$ & $(0.00697)$ & $(0.00721)$ & $(0.00881)$ \\
age & $0.00242^{* * *}$ & 0.000539 & $1.13 \mathrm{e}-05$ & $0.00242^{* *}$ & $0.00272^{* * *}$ \\
& $(0.000362)$ & $(0.000991)$ & $(0.000819)$ & $(0.00100)$ & $(0.00103)$ \\
mne & $0.162^{* * *}$ & $0.154^{* * *}$ & $0.269^{* * *}$ & $0.220^{* * *}$ & $0.370^{* * *}$ \\
& $(0.0172)$ & $(0.0353)$ & $(0.0359)$ & $(0.0616)$ & $(0.136)$ \\
sectors & Yes & Yes & Yes & Yes & Yes \\
regions & Yes & Yes & Yes & Yes & Yes \\
Constant & $4.136^{* * *}$ & $4.338^{* * *}$ & $4.582^{* * *}$ & $4.589^{* * *}$ & $4.222^{* * *}$ \\
Observations & $(0.0180)$ & $(0.0673)$ & $(0.0694)$ & $(0.101)$ & $(0.154)$ \\
& 65,826 & 7,555 & 7,392 & 7,255 & 6,733 \\
& 0.139 & 0.121 & 0.125 & 0.107 & 0.175 \\
\hline
\end{tabular}

Robust standard errors in parentheses $* * * \mathrm{p}<0.01, * * \mathrm{p}<0.05, * \mathrm{p}<0.1$ 


\subsection{Robustness Check 3: A New Algorithm to Identify the Individual Shareholders and Results}

Although there is no information on the ownership type in the original data, we make some further attempts to identify the possible ownership links by non-companies such as individuals, families or states through a new algorithm. In the main text, we do not differentiate between the ultimate beneficial owners and the parent companies, which results in some groups belonging to type (a) in Figure 5 being treated as type (c). The new algorithm first identifies all the nodes with no inward link to the groups where there is at least one Italian company or non-company. ${ }^{18}$ If they have shareholder data in the original ORBIS database but with only minority shareholders or their BvD ID number can be found in AIDA, we can confirm that they are the parent companies. Otherwise, we check the number of outward links they have. If they have more than 1 outward link, we assume that they are individual or family ultimate beneficial owners who control multiple companies (see type (b) in Figure 5 ); thus, the group size of type (b) is 1 less than the previous measure. If they have only 1 outward link, we assume that they are the ultimate controlling shareholder of the parent company (see type (a)). We then remove their links to the parent company and recompute the centrality and the other network measures for the firms belonging to groups of type (a). Some groups of size 2 are thus divided into two disconnected nodes, and the firms used to be part of such groups are excluded from the sample. We finally derive a new sample of 183,177 Italian firms that belong to corporate groups. Nevertheless, the main regression results of the new algorithm and the previous one in this chapter are generally consistent (see details in Table 12 and Table 13). It should be noted that this new algorithm may mistakenly drop some ownership links by companies or institutions whose shareholder data are not covered by ORBIS. The results reported here aim only to provide further support for our findings in this paper.

\footnotetext{
${ }^{18}$ The BvD ID number in ORBIS provides the nationality information of an entity or individual.
} 


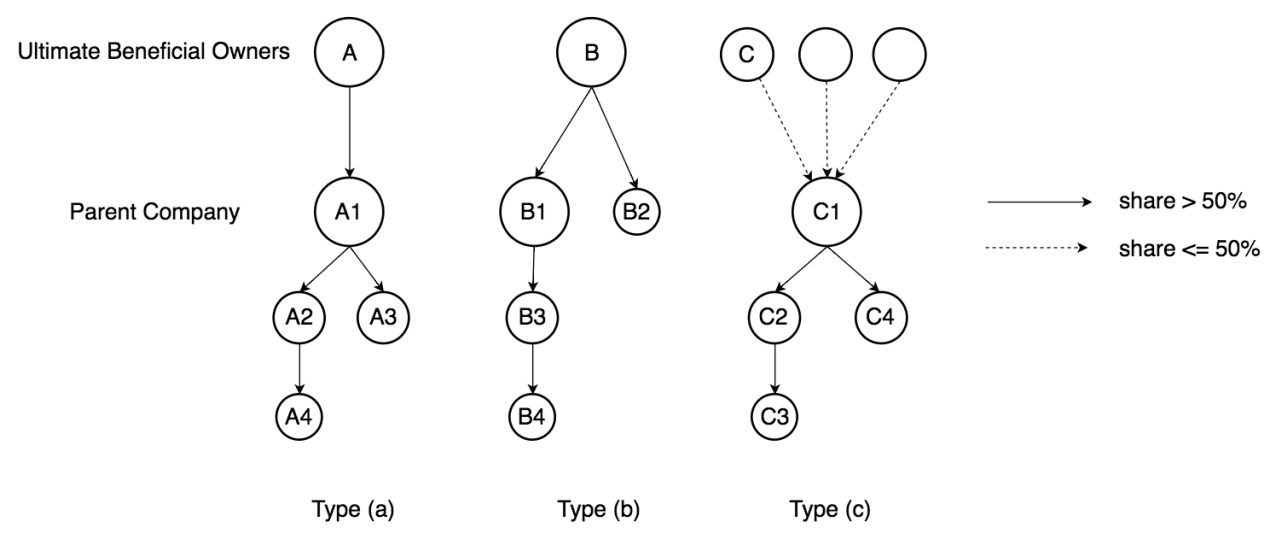

Figure 5: Three Cases of Corporate Groups' Ownership Structure 
Table 12: Regression Results of Centrality and Corporate Group Size

\begin{tabular}{|c|c|c|c|c|c|c|c|}
\hline \multicolumn{8}{|c|}{ Dependent variable: 3 -year average sales growth rate } \\
\hline & (1) & $(2)$ & $(3)$ & $(4)$ & $(5)$ & (6) & (7) \\
\hline VARIABLES & Sales growth & Sales growth & Sales growth & Sales growth & Sales growth & Sales growth & Sales growth \\
\hline \multirow[t]{2}{*}{ ownership level } & -0.00408 & $-0.00558^{*}$ & -0.00420 & & & & 0.00319 \\
\hline & $(0.00258)$ & $(0.00287)$ & $(0.00283)$ & & & & $(0.00297)$ \\
\hline \multirow[t]{2}{*}{ centrality } & & & & $0.0351^{* * *}$ & $0.0530^{* * *}$ & $0.0520^{* * *}$ & $0.0551^{* * *}$ \\
\hline & & & & $(0.00509)$ & $(0.00817)$ & $(0.00817)$ & $(0.00875)$ \\
\hline \multirow[t]{2}{*}{$(\log )$ No. firms } & 0.00444 & $0.00664^{* *}$ & & $0.00664^{* *}$ & $0.00687^{* *}$ & & \\
\hline & $(0.00301)$ & $(0.00334)$ & & $(0.00273)$ & $(0.00283)$ & & \\
\hline \multirow[t]{2}{*}{ PI } & & $0.0386^{* * *}$ & $0.0342^{* * *}$ & & $0.0193^{*}$ & 0.0160 & 0.0130 \\
\hline & & $(0.0114)$ & $(0.0112)$ & & $(0.0114)$ & $(0.0114)$ & $(0.0116)$ \\
\hline \multirow[t]{2}{*}{ diameter } & & & 0.00204 & & & $0.00245^{* *}$ & 0.00185 \\
\hline & & & $(0.00142)$ & & & $(0.00121)$ & $(0.00137)$ \\
\hline \multirow[t]{2}{*}{ (log) No. employees } & $0.0488^{* * *}$ & $0.0469^{* * *}$ & $0.0469^{* * *}$ & $0.0480^{* * *}$ & $0.0457 * * *$ & $0.0457^{* * *}$ & $0.0458^{* * *}$ \\
\hline & $(0.00247)$ & $(0.00268)$ & $(0.00269)$ & $(0.00246)$ & $(0.00268)$ & $(0.00268)$ & $(0.00269)$ \\
\hline \multirow[t]{2}{*}{ (log) capital intensity } & $0.00429^{* * *}$ & $0.00442^{* * *}$ & $0.00451^{* * *}$ & $0.00355^{* * *}$ & $0.00364^{* * *}$ & $0.00371^{* * *}$ & $0.00374^{* * *}$ \\
\hline & $(0.000990)$ & $(0.00108)$ & $(0.00108)$ & $(0.000994)$ & $(0.00109)$ & $(0.00109)$ & $(0.00109)$ \\
\hline \multirow[t]{2}{*}{$(\log )$ sales 2014} & $-0.0655^{* * *}$ & $-0.0623^{* * *}$ & $-0.0622^{* * *}$ & $-0.0660^{* * *}$ & $-0.0629^{* * *}$ & $-0.0628^{* * *}$ & $-0.0629 * * *$ \\
\hline & $(0.00231)$ & $(0.00252)$ & $(0.00252)$ & $(0.00232)$ & $(0.00253)$ & $(0.00252)$ & $(0.00252)$ \\
\hline \multirow[t]{2}{*}{ mne } & $0.0336^{* * *}$ & $0.0304^{* * *}$ & $0.0355^{* * *}$ & $0.0291^{* * *}$ & $0.0258 * * *$ & $0.0312^{* * *}$ & $0.0306^{* * *}$ \\
\hline & $(0.00522)$ & $(0.00579)$ & $(0.00538)$ & $(0.00532)$ & $(0.00588)$ & $(0.00546)$ & $(0.00550)$ \\
\hline \multirow[t]{2}{*}{ age } & $-0.00112^{* * *}$ & $-0.00112^{* * *}$ & $-0.00112^{* * *}$ & $-0.00120^{* * *}$ & $-0.00120^{* * *}$ & $-0.00120^{* * *}$ & $-0.00120^{* * *}$ \\
\hline & $(0.000129)$ & $(0.000150)$ & $(0.000149)$ & $(0.000132)$ & $(0.000153)$ & $(0.000153)$ & $(0.000153)$ \\
\hline sectors & Yes & Yes & Yes & Yes & Yes & Yes & Yes \\
\hline regions & Yes & Yes & Yes & Yes & Yes & Yes & Yes \\
\hline \multirow[t]{2}{*}{ Constant } & $0.473^{* * *}$ & $0.444^{* * *}$ & $0.446^{* * *}$ & $0.469^{* * *}$ & $0.446^{* * *}$ & $0.450^{* * *}$ & $0.448^{* * *}$ \\
\hline & $(0.0144)$ & $(0.0157)$ & $(0.0157)$ & $(0.0143)$ & $(0.0157)$ & $(0.0157)$ & $(0.0157)$ \\
\hline Observations & 82,597 & 64,662 & 64,662 & 82,601 & 64,662 & 64,662 & 64,662 \\
\hline R-squared & 0.035 & 0.032 & 0.032 & 0.036 & 0.033 & 0.033 & 0.033 \\
\hline
\end{tabular}


Table 13: Regression Results of Subsamples by Corporate Group Sizes

\begin{tabular}{|c|c|c|c|c|c|}
\hline \multicolumn{6}{|c|}{ Dependent variable: 3-year (2014-2016) average sales growth rate } \\
\hline & $(1)$ & $(2)$ & $(3)$ & (4) & $(5)$ \\
\hline VARIABLES & Size $3-5$ & Size 6-7 & Size 8-13 & Size $14-50$ & Size $50+$ \\
\hline \multirow[t]{2}{*}{ centrality } & $0.0680^{* * *}$ & 0.0401 & 0.0281 & $0.0664^{*}$ & 0.0124 \\
\hline & $(0.00987)$ & $(0.0259)$ & $(0.0252)$ & $(0.0359)$ & $(0.0457)$ \\
\hline \multirow[t]{2}{*}{ PI } & $0.0232^{*}$ & -0.0290 & 0.00284 & 0.0243 & 0.200 \\
\hline & $(0.0123)$ & $(0.0443)$ & $(0.0642)$ & $(0.0987)$ & $(0.269)$ \\
\hline \multirow[t]{2}{*}{$(\log )$ No. employees } & $0.0474^{* * *}$ & $0.0508^{* * *}$ & $0.0328^{* * *}$ & $0.0343^{* * *}$ & $0.0427 * * *$ \\
\hline & $(0.00365)$ & $(0.00937)$ & $(0.00886)$ & $(0.00832)$ & $(0.00619)$ \\
\hline \multirow[t]{2}{*}{ (log) capital intensity } & $0.00335^{* *}$ & 0.00521 & 0.00150 & 0.00433 & 0.00385 \\
\hline & $(0.00147)$ & $(0.00353)$ & $(0.00326)$ & $(0.00329)$ & $(0.00271)$ \\
\hline \multirow[t]{2}{*}{$(\log )$ sales 2014} & $-0.0705^{* * *}$ & $-0.0646^{* * *}$ & $-0.0462^{* * *}$ & $-0.0544^{* * *}$ & $-0.0495^{* * *}$ \\
\hline & $(0.00330)$ & $(0.00919)$ & $(0.00823)$ & $(0.00890)$ & $(0.00607)$ \\
\hline \multirow[t]{2}{*}{ age } & $-0.00146^{* * *}$ & $-0.000918^{* *}$ & $-0.000811^{*}$ & -0.000683 & $-0.000932^{* *}$ \\
\hline & $(0.000173)$ & $(0.000468)$ & $(0.000449)$ & $(0.000422)$ & $(0.000466)$ \\
\hline \multirow[t]{2}{*}{ mne } & $0.0212^{* * *}$ & 0.0215 & -0.00388 & $0.0352^{*}$ & $0.0809^{* * *}$ \\
\hline & $(0.00815)$ & $(0.0158)$ & $(0.0138)$ & $(0.0183)$ & $(0.0310)$ \\
\hline sectors & Yes & Yes & Yes & Yes & Yes \\
\hline regions & Yes & Yes & Yes & Yes & Yes \\
\hline \multirow[t]{2}{*}{ Constant } & $0.510^{* * *}$ & $0.473^{* * *}$ & $0.350^{* * *}$ & $0.397^{* * *}$ & $0.259^{* * *}$ \\
\hline & $(0.0204)$ & $(0.0577)$ & $(0.0492)$ & $(0.0598)$ & $(0.0525)$ \\
\hline Observations & 42,479 & 5,239 & 5,478 & 5,838 & 5,628 \\
\hline R-squared & 0.039 & 0.036 & 0.021 & 0.032 & 0.029 \\
\hline
\end{tabular}

Robust standard errors in parentheses

$$
\text { *** } \mathrm{p}<0.01,{ }^{* *} \mathrm{p}<0.05,{ }^{*} \mathrm{p}<0.1
$$

